Abant Tıp Dergisi

Olgu Sunumu / Cilt 10 Sayı 3 YII 2021
Abant Medical Journal

Case Report / Volume 10 Issue 3 Year 2021

\title{
Nadir Bir Lenfadenopati Nedeni Olarak Kedi Tırmığı Hastalığı; Bir Olgu Sunumu
}

Cat Scratch Disease as a Rare Cause of Lymphadenopath; A Case Report

\author{
Önder KILIÇASLAN ${ }^{1}$ (i) , Didem Kızmaz IŞANÇLI ${ }^{1}$ (iD) , Esmanur FiL ${ }^{2}$ (D) ${ }^{2}$ Adem KARBUZ ${ }^{1}$ (iD) \\ ${ }^{1}$ Prof Dr Cemil Taşçıoğlu Şehir Hastanesi Çocuk Enfeksiyon Kliniği, İstanbul, Türkiye \\ 2 Prof Dr Cemil Taşçıoğlu Şehir Hastanesi Çocuk Sağlığı ve Hastalıkları Bölümü, İstanbul, Türkiye
}

\section{Öz}

Kedi tırmı ı̆ı hastalığı Bartonella Henselae tarafından meydana gelir. Kedilerin tırnakları ile oluşturduğu çizikler veya ısırma yolu ile bulaşır. Tek taraflı ağrılı aksiller lenfadenopati ile başvuran 14 yaş kız hastayı kedi tırmığı hastalığı tanısı alması nedeniyle sunduk. Öyküsünde yavru kediler ile teması olduğu öğrenildi. Tetkiklerinde beyaz küre sayısı 17630 uL, C-Reaktif protein $30 \mathrm{mg} / \mathrm{L}$, sedimentasyon $42 \mathrm{~mm} / \mathrm{saat}$ saptandı. Sağ aksiller yüzeyel ultrasonografik incelemesi ve magnetik rezonans görüntülemesi abse ve lenfadenopati olarak yorumlandı. Hastaya sulbaktam-ampisilin ve azitromisin başlandı. Ayırıcı tanıda araştırılan viral ve tipik bakteriyel etkenlere yönelik testler negatifti. Abse drenajından alınan örneğe yönelik yapılan tetkiklerde Bartonella henselae Real Time PCR ve serum Bartonella henselae IgG sonucu pozitif saptandı. Tek taraflı lokalize lenfadenopati nedeniyle başvuran hastalarda kediler ile temas irdelenmeli, ayırıcı tanı özenle yapılmalıdır.

Anahtar Kelimeler: Çocuk, Kedi, Kedi Tırmığı Hastalığı, Lenfadenopati

\section{Abstract}

Cat scratch disease is caused by Bartonella Henselae. It is transmitted by scratches or bites of cats. We report a 14year-old female patient who presented with unilateral painful axillary lymphadenopathy, since she was diagnosed with cat scratch disease. She had close contact with kittens in her medical history. In laboratory findings white blood cell count was 17630 ul, C-Reactive protein $30 \mathrm{mg} / \mathrm{L}$, sedimentation was $42 \mathrm{~mm} /$ hour. Superficial ultrasonographic examination and magnetic resonance imaging of right axillary area showed abscess and lymphadenopathy. Sulbactam ampicillin and azithromycin were given to the patient. Tests for viral and typical bacterial agents were negative in the differential diagnosis. Abcess drainage specimen was found to be positive for Bartonella henselae Real Time PCR and serum Bartonella henselae IgG was positive. In patients presenting with unilateral localized lymphadenopathy, history of close contact with the cats should be questioned and the differential diagnosis should be made carefully.

Keywords: Child, Cat, Cat Scratch Disease, Lymphadenopathy

\section{GiRiş}

Kedi tırmığı hastalığı (KTH) Bartonella henselae (B. henselae) tarafından meydana gelen zoonotik bir hastalıktır. Insanlara kedilerin tırnakları ile oluşturduğu çizikler veya ısırma yolu ile bulaşır. Genellikle bağışıklı̆ı yeterli hastaları, özellikle çocukları ve gençleri etkiler ve sıklıkla 4-6 hafta arasında kendiliğinden iyileşme ile seyreden iyi huylu, kendi kendini sınırlayan bir hastalıktır. Çoğunlukla bakterinin vücuda giriş bölgesine yakın bölgesel lenfadenopati (LAP) ile karakterizedir. En çok etkilenen lenf düğümleri aksiller ve servikal lenf dügümleridir (1). Abse oluşumu ile gelişen süpüratif LAP, birçok vakada hastalığın doğal seyrinde görülebilmektedir. Abse formasyonu gelişmiş lenf düğümleri, ağrısız da çok ağrılı da olabilir (2). Biz de tek taraflı ağrıı aksiller LAP ile başvuran 14 yaşında kız hastayı, ayrıcı tanı sonrasında nadir bir LAP nedeni olan KTH tanısı alması sebebiyle sunduk.

\section{OLGU}

Bilinen hastalık öyküsü olmayan 14 yaş kız hasta; yaklaşık 10 gün önce sağ koltuk altında ağrılı şişlik gelişmesi ve 5 gün süre ile amoksisilin-klavulonik asit kullanımı olmasına rağmen şikayetlerinin 
devamı üzerine tarafımıza başvurdu. Hastanın ateş dahil ek şikayeti bulunmamaktaydı. Öyküsünde ev içinde yıllardır kedi beslediği, ev dışında da sokak kedileri ile temas halinde olduğu ve kedilerin sıklıkla hastayı tırmaladığı ve ısırdığı öğrenildi. Muayenesinde sağ koltuk altında $3 \times 4$ $\mathrm{cm}$ büyüklüğünde sert, ağrılı ve mobil kitlesel lezyon (LAP? abse?) mevcut olan hastanın diğer sistem muayeneleri doğaldı. Hepatosplenomegali ve aksiller bölge dışında başka bir bölgede LAP saptanmadı. Tetkiklerinde hemoglobin değeri $13 \mathrm{~g} / \mathrm{L}$, beyaz küre sayısı 17630 uL, nötrofil sayısı 15430 uL, lenfosit sayısı 1500 uL, trombosit sayısı 293000 uL, C-Reaktif protein $30 \mathrm{mg} / \mathrm{L}$, sedimentasyon $42 \mathrm{~mm} / \mathrm{saat}$ saptandı. Karaciğer fonksiyon testleri, koagulasyon testleri, böbrek fonksiyon testleri ve elektrolitleri normal sınırlarda idi. Periferik yaymada sola kayma mevcut olup atipik hücre veya blast görülmedi. Sağ aksiller yüzeyel ultrasonografide (USG) $27 \times 35 \mathrm{~mm}$ boyutunda abse veya LAP ile uyumlu görüntü gözlemlendi. Abdominal USG'de patoloji izlenmedi. Tetkik ve tedavi için yatırılan hastaya $200 \mathrm{mg} / \mathrm{kg} /$ gün intravenöz (IV) sulbaktam-ampisilin, kedi tırmığı hastalığını düşündüren öykü vermesi sebebiyle de oral azitromisin ve kilosuna göre intiyacına uygun IV hidrasyon başlandı. Lenfadenopati ayrıcı tanısında olası enfeksiyoz etkenlere yönelik yapılan tetkiklerde Toxoplazma immunglobulin (Ig) M, Sitomegalovirüs (CMV) IgM, Parvovirüs IgM, Mycoplasma pneumoniae IgM testleri ile Epstein-Barr virüs (EBV) anti-viral kapsid antijen (VCA) IgM negatif saptandı. Boğaz ve kan kültüründe üreme olmadı. Postero-anterior akciğer grafisinde (PAAG) patoloji yoktu ve tüberkülin deri testinde (TDT) endurasyon saptanmadı. Lenfadenopatinin boyutu ve derinliğinin değerlendirilmesi açısından hastaya yapılan kontrastlı magnetik rezonans (MR) görüntülemesinde lezyon; şüpheli nekrotik LAP ve abse şeklinde yorumlandı. Lezyon boyutunun takibi açısından kontrol USG çekildi; küçülme görülmemesi ve ağrının devamı üzerine abseye yönelik iğne aspirasyon ile drenaj uygulandı.
Hastada azitromisin tedavisi 10 güne, sulbaktamampisilin tedavisi ise 14 güne tamamlandı. Örnekten alınan tetkiklerde ARB ve mikobakteri polimeraz zincir reaksiyon (PCR) testleri negatif tespit edilirken, abse kültüründe üreme saptanmadı. Gram boyamada ise yoğun polimorfonükleer lökosit görülürken mikroorganizma görülmedi. Abse materyalinden gönderilen $B$. henselae Real Time PCR sonucu ve serum $B$. henselae $\lg G$ sonucu (1/1024 titre) ise pozitif saptandı. Kedi tırmığı hastalığı olarak kabul edilen hasta yatışının 18. gününde aktif şikayetinin olmaması nedeniyle taburcu edildi. Kontrol muayenelerinde hastanın şikayetleri tamamen düzeldi ve fizik muayenede patoloji saptanmadı.

\section{TARTIŞMA}

Bebeklik Kedi tırmığı hastalı̆̆ı, Bartonella türlerinin neden olduğu en yaygın enfeksiyondur. Amerika Birleşik Devletleri'nde (ABD), 9.3/10.000 hasta olarak hesaplanan insidansı ile göze çarparken, yine $A B D^{\prime}$ de pediatrik insidansının 4.5/100.000 hasta olduğu tahmin edilmektedir. Hastalık her yaştan insanda meydana gelse de, hastaların çoğu 18 yaşın altındadır. Bunun nedeni olarak; çocukların kedilerle daha fazla yakın temas halinde olma ihtimallerinin olması düşünülmektedir (3). Bartonella henselae kediler arasında pire (Ctenocephalides felis) veya pire dışkısı yoluyla bulaşır. Enfekte kedide B. henselae, pire tarafından yutulan kırmızı kan hücrelerinde yaşar ve bakteri pirenin bağırsağında hayatta kalır. Hatta B. henselae ortama saçılan pire dışkısı içinde en az 9 gün canlı kaldığı bilinmektedir. Kedinin derisinde biriken kontamine pire dışkısı, kaşınma sırasında kedinin pençelerinin altına girer. Kedinin tırmalaması ile de organizma insanlar da dahil olmak üzere diğer hayvanlara bulaşır. Bu en yaygın bulaşma şeklidir (4). Bizim hastamız da beklenildiği gibi 14 yaşında idi. Ev içinde ve dışında yıllardır kediler ile temas halinde olduğu ve kedilerin sık sık hastayı tırmaladığı veya ısırdığı öğrenildi. Bu bilgi bizim için ayrıcı tanıda KTH düşünmemizdeki en önemli etken olmuştur. 
Kedi tırmığı hastalığı genellikle inokulasyon bölgesinde eritemli papüllerle başlar ve bölgesel LAP 1-3 hafta sonra ortaya çıkar. Vakaların çoğunda, LAP tipik olarak, genellikle koltuk altı ve epitroklear düğümlerde (\%46), baş ve boyun (\%26) ve kasıkta $(\% 17,5)$ görülürken önemli bir özelliği tutulumun tek taraflı lenf düğümünü içermesidir (5). Lenfadenit aylarca devam edebilir ve hatta bazı hastalarda 12-24 ay kadar uzun bir süre lenf nodu büyümesi görülebilir. Çoğu hastada enfeksiyon kendi kendini sınırlar, ateş olmaz ve sistemik belirti görülmez (6). Hastamız da literatür ile uyumlu olacak şekilde lenf bezi tutulumu tek taraf ve en sık saptanan bölge olan aksiller lenf düğümleri tutulumu ile karşımıza geldi.

Enfekte kişilerin \%5-25'inde karaciğer ve/veya dalak granülomları, merkezi sinir sistemi tutulumu (ensefalit), odağı bilinmeyen ateş, subakut bakteriyel endokardit, osteomiyelit, pnömoni, glomerülonefrit, oküler tutulum (Parinaud oküloglandüler sendrom, nöroretinit, retinokoroidit) gibi atipik sistemik hastalık bulguları saptanabilir. Uzamış ateş ile karın ağrısı olan $\mathrm{KTH}^{\prime} \mathrm{l}$ । bir hastada \%53 oranında hepatomegali ve/veya splenomegali saptanabilir. Abdominal görüntülemede ise hastaların $\% 50$ 'sinden fazlasında karaciğer veya dalakta mikro abseler tespit edilebilir $(3,5)$. Hastamızda lenf bezi tutulumu dışında tutulum yoktu. Abdominal USG'de organomegali veya abse bulunamadı. Diğer sistem tutulumunu düşündürecek şikayet, fizik muayene ve laboratuvar bulgusu saptanmadı.

Kedilerin yaklaşık \%50'si asemptomatik B. henselae taşıyıcılarıdır. Özellikle kronik bakteriyemisi olan ve bakterileri tükürüklerinde taşıyan küçük kediler, insanları ısırarak ve tırmalayarak aktarıcı görev üstlenir. Kedi pireleri, hastalı̆ın kediden kediye yatay geçişinden sorumludur ve bazen hastalığı insanlara bulaştırabilirler. Bu nedenlerden ötürü hikayede kedi teması aranması tanı koymada büyük önem taşımaktadır (3). Bartonella henselae kültürde zor üreyen bir gram negatif basildir. Bu sebeple tanıda rutin kültür uygulaması tavsiye edilmez. Tanı için başlangıç sıklıkla serolojik testler ile olmaktadır. Serolojik testler kültürden daha duyarlı olmasına rağmen, özgüllükten yoksundur. Çünkü asemptomatik birçok kişi, daha önce kaldıkları maruziyet nedeniyle pozitif serolojiye sahiptir. Özelikle kedi sahiplerinde yüksek oranda pozitiflik beklenmektedir. Bartonella IgG titresinin 1:64'ün altında olması hastada enfeksiyonun olmadığını, 1:64 ile 1:256 arasında olması olası enfeksiyonu, 1:256'dan büyük titreler ise aktif veya yakın zamanda geçirilmiş enfeksiyonu göstermektedir. Olası enfeksiyon düşünüldüğünde bu hastalarda 10-14 gün içinde test tekrar yapılmalıdır (7). Pozitif bir IgM testi ise akut hastalığı düşündürür. Ancak IgM üretiminin 3 ay gibi bir süre için mümkün olup kısa süreli saptanması, bazen saptanamayan seviyede kalması, bakteriyemik fazda antikor oluşmayabilmesi gibi nedenlerden dolayı kullanımı sınırlı kalmaktadır. Bilinmelidir ki negatif IgM sonucu hastalığı dışlamamaktadır. Örneklerden istenen PCR testi ile ise farklı Bartonella türleri tespit edilebilir; özgüllük çok yüksektir, ancak duyarlılık serolojiye göre daha düşüktür (8). Hastamızın da kedi ile oynama hikayesi mevcuttu. Abseye uygulanan aspirasyon örneğinde B. henselae Real Time PCR ve serum $B$. henselae IgG sonucu $1 / 1024$ titre ile pozitif saptandı. Böylece hasta KTH tanısı almış oldu.

Kedi tırmı ı̆ı hastalığı genellikle çocuklarda teşhis edilir, ancak yetişkinlerde de kendini gösterebilir. Hastaların \%85-90'ında lokal LAP saptanır. Tek taraflı LAP saptanan hastalarda kedilere maruz kalma öyküsü olsun olmasın KTH ayırıcı tanıda bulunmalıdır ve ayırıcı tanı çoğunlukla tek taraflı LAP'ın diğer nedenlerini içerir. Grup A streptokok veya Staphylococcus aureus adeniti, CMV, EBV veya Toxoplazma nedenli LAP'lar, mikobakteriyel lenfadenitler ve maligniteler ayırıcı tanıda düşünülmesi gereken başlıca nedenlerdir (7). Hastamızda Toxoplazma IgM, CMV IgM, Parvovirüs IgM, Mycoplasma pneumoniae IgM, EBV VCA IgM negatif saptandı. Boğaz ve kan 
kültüründe üreme olmadı. Ayrıca PAAG ve TDT'de patoloji saptanmadı. Abseden alınan örneklerde de ARB ve mikobakteri PCR negatif saptanırken, sıvı kültüründe üreme saptanmadı. (kısaltmaların açıklamasını yazınız)

Bartonella hensalae enfeksiyonu için immün sistem sorunu olmayan kişilerde antimikrobiyal tedavi tartışmalıdır. Kesin bir tedavi önerisinin oluşturulamamasının nedeni olarak Bartonella enfeksiyonunun genellikle kendi kendini sınırlandırmasından kaynaklandığı düşünülmektedir (9). Yine de bazı antimikrobiyal tedaviler günümüzde kullanılmaktadır. Azitromisin $\mathrm{KTH}^{\prime}$ da önerilen başlıca tedavi ajanıdır. Tedavi süresi olarak 5-10 gün arası kullanımın yeterli olacağı görüşü hakimdir. Ayrıca rifampin, gentamisin, siprofloksasin, trimetoprim-sülfametoksazol, doksisiklin ve klaritromisin tedavilerinin de etkili olabileceği bildirilmiştir (10). Yapılan bir çalışmada KTH ile takip edilen hastalarda \%11,8-48 oranında lenf nodu absesi saptanabileceği vurgulanmaktadır (KAYNAK VERINIZ). Ağrılı veya abse lenf dügümleri olan hastalarda antibiyotik tedavisi yanında hızlı bir rahatlama sağlanacağı için cerrahi drenaj veya iğne aspirasyon tedavisi önerilmektedir (2). Hastamıza başlangıç tanısı belli olmadığı için nonspesifik olarak sulbaktamampisilin ve hastanın kedi ile temas hikayesi olması nedeniyle azitromisin tedavisi başlandı. Ağrı ve şişlik şikayetlerinin 10 günlük tedavi sonrası istenilen ölçüde gerilememesi sonucu hastaya abseye yönelik iğne aspirasyon ile drenaj uygulandı. Müdahale sonrası hastanın ağrısı azaldı, boyutu ciddi oranda küçüldü. Kontrol muayenelerinde LAP bölgesinde tekrardan büyüme veya ağrı gözlenmedi ve zamanla tamamen kayboldu.

Sonuç olarak; KTH tek taraflı LAP nedeniyle başvuran hastalarda muhakkak akla gelmesi gerekmektedir. Hikayede kedi ile temas irdelenmeli, LAP'a yönelik ayırıcı tanı özenle yapılmalıdır. Bazı hastalarda LAP'ın abseleşebileceği, antimikrobiyal tedaviye yanıt alınamadığı abselerde cerrahi veya iğne ile aspirasyon sonucunda dramatik iyileşme sağlanabileceği akılda tutulmalıdır.

Bilgilendirilmiş Onam: Aileden yazılı onam alınmıştır.

Çıkar Çatışması: Yazarlar çıkar çatışması beyan etmemişlerdir.

Finansal Destek: Yazarlar finansal destek beyan etmemişlerdir.

\section{KAYNAKÇA}

1. Bejarano AP, Del Moral RS, Guisado-Gil AB. Bartonella henselae encephalopathy in a paediatric patient: $A$ case report and treatment review. J Clin Pharm Ther. 2020;45(4):840-4. doi: 10.1111/jcpt.13178.

2. Ridder GJ, Boedeker CC, Technau-Ihling K, Sander A. Cat-scratch disease: Otolaryngologic manifestations and management. Otolaryngol Head Neck Surg. 2005;132(3):353-8. doi: 10.1016/j.otohns.2004.09.019.

3. Sandoval AC, Reyes FT, Prado MA, Peña AL, Viviani TN. Cat-scratch Disease in the Pediatric Population: 6 Years of Evaluation and Follow-up in a Public Hospital in Chile. Pediatr Infect Dis J. 2020;39(10):889-93. doi: 10.1097/INF.0000000000002708.

4. Pennisi MG, Marsilio F, Hartmann K, Lloret A, Addie D, Belák $S$, et al. Bartonella species infection in cats: $A B C D$ guidelines on prevention and management. J Feline Med Surg. 2013;15(7):563-9. doi: $10.1177 / 1098612 \times 13489214$.

5. Chang CC, Lee CJ, Ou LS, Wang CJ, Huang YC. Disseminated cat-scratch disease: case report and review of the literature. Paediatr Int Child Health. 2016;36(3):232-4. doi: 10.1179/2046905515Y.0000000005.

6. Prudent E, Lepidi H, Audoly G, La Scola B, Fournier PE, Edouard S, et al. Bartonella henselae is usually not viable in lymph nodes of patients with cat scratch disease. Eur J Clin Microbiol Infect Dis. 2017;36(11):2207-13. doi: 10.1007/s10096-017-3047z.

7. Klotz SA, lanas V, Elliott SP. Cat-scratch Disease. Am Fam Physician. 2011;83(2):152-5.

8. Chaudhry R, Kokkayil P, Ghosh A, Bahadur T, Kant K, Sagar $\mathrm{T}$, et al. Bartonella henselae infection in diverse clinical conditions in a tertiary care hospital in north India. Indian J Med Res. 2018;147(2):189-94. doi: 10.4103/ijmr.IJMR_1932_16.

9. Tey MS, Govindasamy G, Vendargon FM. The clinical spectrum of ocular bartonellosis: a retrospective study at a tertiary centre in Malaysia. J Ophthalmic Inflamm 
Kılıçaslan Ö. ve Ark.

Infect. 2020;10(1):31. doi: 10.1186/s12348-020-

00224-0.

10. Conrad DA. Treatment of cat-scratch disease. Curr Opin Pediatr. 2001;13(1):56-9. doi: 10.1097/00008480200102000-00010. 